\title{
MEET THE DEMONOLOGICAL CHARACTER: TWO TYPES OF NARRATIVE STRUCTURES
}

\author{
Victoria Chervaneva
}

\begin{abstract}
The article describes the system of character nomination in oral demonological narratives about the dead. The syntagmatic level, i.e. the methods of introducing demonic characters and the linguistic tools employed for this purpose, are given particular attention. I also attempt to explain the role this naming system plays in the organisation of a demonological narrative, and show the relationship between character references and storyline of the text.
\end{abstract}

Keywords: demonological character, demonological narrative, function, name, narrative organisation, reference

\section{INTRODUCTION}

In modern studies of oral demonological narratives, which are defined primarily as texts about human contacts with demonic creatures, there are some preference points, or focuses of the researchers' attention, so to speak. In the first place these texts are of interest to scholars as source material providing demonological information, therefore the greatest attention is given to demonological creatures - their functions, attributes, naming patterns, and beliefs associated with them. A look at the bibliography of the subject clearly demonstrates that. ${ }^{1}$

The idea that, in order to understand the specific nature of a demonological text it is crucial to analyse the image of a demonological character, has been well established in folklore studies. The popularity of this idea is indicated by the mere fact that demonological prose compilations are traditionally structured around the type of demonological creatures. Moreover, almost all attempts to systematise demonological prose by topics (mainly in motif-indexes of demonological narratives) are based on classifications by the type of the demonological character (hereinafter DC). ${ }^{2}$

The quite fair view on the $\mathrm{DC}$ as the central semantic point of a demonological text is confirmed by the analysis of demonological prose language. But I would like to draw attention to one point. The way the human being, i.e. the other part of interaction, is represented in a demonological text, is largely a lacuna in the folklorists' knowledge. However, it is the human being only, not the demon, 
that is an obligatory and always verbalised element of the system of actors in demonological narratives. In demonological texts some kinds of supernatural phenomena may well be described without identifying the supernatural actant and without giving its name (moreover, "a mysterious indifference of the informant to the name of demonological phenomena, which he or she talks about" (Levkievskaia 2008: 348) is a typical feature of demonological narratives), but the event of a demonological text is impossible without human participation. The semantic structure of the text implies the existence of an addressee or recipient (in the broadest sense of the term), who receives a certain demonological message (sees or hears the character, is affected by DC's actions).

The researchers' 'mysterious indifference' to the problem of human description in demonological prose is in many ways understandable. The person who interacts with the DC is a representative of 'their' human world, or the pole of norm, and the norm is less interesting than its violation. The norm attracts less attention and is much less verbalised, and its rare verbalisations are not as extensive or distinguished as those of an anomaly (Arutiunova 1988: 307; 1999: 83).

Nevertheless, I have set this research goal and aim to explore the patterns in human image-modelling in demonological texts through the analysis of lexical items. To solve this problem, I used the texts of one thematic group about human contact with the dead. By analysing these texts one can compare the two forms, natural and supernatural, in which human beings are represented, as in most cases both interacting parties of these texts are anthropomorphic.

The material for the analysis consists of 532 demonological stories from the collections published by Zinov'ev (1987), Cherepanova (1996), Pukhova (2009), and Vinogradova and Levkievskaia (2012). The corpus of data comprises the East Slavic mythological texts that were collected on the territory of Russia, Ukraine, and Belarus in the 20th century. Thus the texts represent different local traditions - Siberia, the Russian North, the south of Russia, and Polesye. So representativeness of the sample and abstraction from the narrow local characteristics of the material are ensured.

During the preliminary phase of the study, I found all lexical units that represent and characterise a person, and then classified them into categories: characters, their features (attributes), and actions (predicates). This material made obvious which categorisation parameters of human characters are relevant for the studied texts and helped to determine the subject for the analysis, i.e. the types of human beings appearing in the text.

The analysis showed that the most frequent parameter describing a person in a demonological narrative is the actor's function. According to their function in the studied texts the characters fall into five types. 
1. Demonological character - the dead.

2. Recipient - the person who receives the mythological message, 'reads' it, and thus interacts with the demonological creature. It is important that the recipient is a common human in a position equal to that of the listener and the narrator (while in memorates the recipient and the narrator are usually one and the same person). The recipient's 'commonness' (alive, profane, common person in society) is his or her normative feature, a sign that the actor is included in society, and a necessary condition to consider the information in a demonological text reliable. It is impossible to imagine a situation when the narrator is a magic specialist, as the teller always takes the position outside the sphere of the supernatural.

\section{Characters who are not in contact with the demonological creature -} usually family members, relatives and neighbours of the recipient, i.e. people from the immediate social environment. Their function is to identify, in terms of tradition, what is happening with someone in close proximity: they reveal the true demonic nature of the demonological creature, return the recipient to the reality and save him or her from the harmful influence of supernatural forces. 4. Generalised agent - people from a distant social environment (referred to as people, everybody, every man). As a rule, they perform some usual actions prescribed by tradition. Most often, actions of the generalised agent are described by overtly subjectless sentences (in Russian grammatical tradition they are analysed as indefinite-personal or generalised-personal sentences). Cf.:

... So they opened the coffin, and there she lies, and her dress has three spots on it, three days old (Cherepanova 1996: № 48).

They buried one woman in shoes (Pukhova 2009: № 550).

They buried her, and her daughters were all alone (Zinov'ev 1987: № 83).
... Tak otkryli grob-to, a ona i pravda, lezhit, a na plat'e tri piatna, trekhdnevnoi davnosti (Cherepanova 1996: № 48).

U nas odnu khoronili v tufliakh (Pukhova 2009: № 550).

Ee pokhoronili, a docheri sovsem odni ostalis' (Zinov'ev 1987; № 383).

5. Narrator - a storyteller, in texts where he or she is distinguished from the recipient of the demonological phenomenon. This type of person in the texts has different degrees of verbal representation. Quite often, the narrator does not manifest him/herself at the lexical level, and in some cases self-reference appears by the 1st person pronouns ('I'), or other characters' direct speech is addressed to him or her ('you', etc.). 
Thus, the lexical-thematic field 'person' (all lexical items denoting a person) in the demonological prose is formed of five groups differentiated on a functional basis. It is important that among people mentioned in the text there are none that would not perform any function. The first type (demonological charactera dead person) corresponds to the first term of the binomial 'supernatural/ natural', and in this sense is opposed to the other four types representing a human being in his or her natural incarnation. The narrator, the recipient, and people from their social environment are always portrayed as being outside the world of the supernatural and having the same pattern of world perception as the audience.

Next I classified all words referring to these five types of actors by parameters $\mathrm{N}$ (names), $\mathrm{P}$ (predicates), and A (attributes), which gave a result of 15 lexicalthematic groups. With this approach, practically all the vocabulary in the text is involved in the analysis (only such parameters as 'localisation' and 'temporal characteristics' are left outside the database).

Then I carried out content analysis of the vocabulary for actors from a thematic-ideographic point of view, and also statistical analysis. I examined character names as well as references to their attributes: a) permanent (gender, age, appearance, marital status, social characteristics (occupation, property, etc.), intellectual qualities, spiritual (ethical) characteristics) and b) processual (nature of actions they perform).

Such an analysis produces results that are interesting, first of all, as compared to general linguistic data or the specifics of human image modelling in other folklore genres and other semiotic systems: fiction, 'naive' literature, belles-lettres, memoirs, and others. To understand the mechanisms of narrative organisation, however, we should apply the syntagmatic analysis of lexical items (i.e. analyse the order in which the items of specific parameters appear) and pragmatic analysis, which allows to identify the relationship between the verbal representation of parameters, on the one hand, and the plotline of the text as well as the communicative situation in which it lives, on the other.

In this article I will describe only two of the five types of demonological narrative actors (DC and recipient), focusing on their naming. Moreover, in terms of the syntagmatic relations between these lexical units I will characterise only the act of introduction (a text fragment introducing the new character).

The empirical basis for the study provides 1,936 lexical items - references to the DC (863 items) and to the recipient (1,073 items), which have different semantic and grammatical characteristics:

- names of demonological characters (dead man);

- $\quad$ proper nouns (Ivan, Natalia);

- words with general categorical semantics (a woman, old man);

- $\quad$ kinship terms (brother); 
- names indicating social environment (neighbour);

- naming by profession/job (blacksmith)/ property relations (house owner);

- names of animals (DC transformations: crow, dove);

- verbal references (it is rustling);

- $\quad$ pronouns (she, it, I, someone);

- metonymic references (part of body as character: head/foot);

- evaluative characteristics as references (fool, sinner).

Below they are presented in order of decreasing frequency in the corpus of examined texts.

\begin{tabular}{|c|c|}
\hline Demonological character & Recipient \\
\hline pronouns - $448(51.91 \%)$ & pronouns - $777(72.41 \%)$ \\
\hline kinship terms - 177 (20.51\%) & kinship terms - $130(12.12 \%)$ \\
\hline $\begin{array}{l}\text { words with the general categorical } \\
\text { semantics 'a person' - } 88(10.2 \%)\end{array}$ & $\begin{array}{l}\text { words with the general categorical } \\
\text { semantics 'a person' - } 99(9.23 \%)\end{array}$ \\
\hline \multicolumn{2}{|l|}{$\begin{array}{l}\text { names of demonological } \\
\text { characters }-66(7.65 \%)\end{array}$} \\
\hline proper nouns - $36(4.17 \%)$ & proper nouns $-41(3.82 \%)$ \\
\hline \multicolumn{2}{|l|}{$\begin{array}{l}\text { names of animals (transformations } \\
\text { of DC) }-16(1.85 \%)\end{array}$} \\
\hline $\begin{array}{l}\text { naming by profession / job / } \\
\text { property relations }-9(1.04 \%)\end{array}$ & $\begin{array}{l}\text { naming by profession / job / } \\
\text { property relations - } 9(0.84 \%)\end{array}$ \\
\hline $\begin{array}{l}\text { names of people from the social } \\
\text { environment }-3(0.35 \%)\end{array}$ & $\begin{array}{l}\text { names of people from the social } \\
\text { environment - } 10(0.93 \%)\end{array}$ \\
\hline \multicolumn{2}{|l|}{$\begin{array}{l}\text { verbal references (verb as reference } \\
\text { to a person) }-9(1.04 \%)\end{array}$} \\
\hline \multicolumn{2}{|l|}{ metonymic reference $-9(1.04 \%)$} \\
\hline $\begin{array}{l}\text { evaluative characteristics as } \\
\text { reference }-2(0.23 \%)\end{array}$ & $\begin{array}{l}\text { evaluative characteristics as } \\
\text { reference }-7(0.65 \%)\end{array}$ \\
\hline
\end{tabular}

I would like to draw attention to the following features of character names in demonological stories. Firstly, DC names are more diverse than those of the recipients, and among them there are specific ones, such as direct names of demonological characters, names of transformations into an animal, specific verbal references to the DC designating its action in the complete absence of substantive, metonymic references (note that this way of naming the character could also be used to refer to the recipient; there are no semantic constraints). 
Paradoxically, when calculating word usages in folk demonological stories, it becomes clear that the dead man in the Russian folk tradition is rarely referred to as 'dead'. In the analysed text corpus names for a dead person (dead man, dead, drowned man, and others), and the words qualifying it as a supernatural character (evil spirits, devil, ghost, spirit, soul, etc.), constitute only about $8 \%$ of all the names. Moreover, such names are used, as a rule, in conclusions and explanations, i.e. in constructions that are placed outside the story's plot. Most of the names for demonological characters are words that categorise them as human beings (anthroponyms in the broadest sense).

Secondly, the analysis reveals lexical poverty of demonological narratives, especially in the lexical-semantic field 'recipient'. It becomes especially obvious if we compare the obtained data with the corresponding fragment of the national linguistic worldview, which is described in the works of Yuri Apresian (1995), Nina Arutiunova (1999 [1998]), Elena Uryson (1998), Aleksei Shmelev (2002), Anna Wierzbicka (1997), and with the data from dictionaries. For example, in the Russian Semantic Dictionary the semantic field 'human being' is represented by nearly 400 pages, the table of contents itself taking 10 pages (RSD 1998). In folk prose texts many parameters describing a person are absent; for example, there are almost no emotional, imaginative, or expressive components in the meanings of words serving as names.

Characteristics of a person by job and profession are irrelevant for demonological narratives. The language of demonological prose shows that the person is included in the society primarily at the family level. A considerable quantity of kinship terms, compared to a small number of social group characteristics, is obviously due to the content of the studied texts related to the family and family relationships.

An important feature of demonological narratives about the dead is the frequency of pronominal references to a human being, first of all through personal pronouns - in the narrator's speech, as well as in direct and indirect speech of the characters. There are several reasons for this. On the one hand, demonological stories, being included in a dialogue and integrated into a situation of direct communication, acquire features inherent in colloquial speech. It is known that pronoun is the most common content word in colloquial speech, which is due to the importance of direct communication of anaphoric functions inherent in pronouns (Zemskaia 1979: 72; RCS 1983: 138-139). Thus, the 1st person pronoun ('I') is a usual way of the narrator's self-reference. The second reason for the widespread use of pronominal references to the DC is in the genre's pragmatics, that is, the narrator's intention to avoid direct names of supernatural phenomena or agents (Levkievskaia 2006: 197-198).

However, in the analysis of names in folklore texts little is achieved or explained by looking at the range of lexemes. The study of their syntagmatics in 
the text proves to be much more useful. For references to characters of different types, this approach reveals a number of rules, as well as the relationship between these references, on the one hand, and the storyline and event sequence in the text, on the other.

'Reference', here understood as correlation between the sign (word, phrase) and the object of extralinguistic reality in the communication process (Arutiunova 1990), varies depending on the differences between the interlocutors' knowledge on the discussed matter. If the subject discussed is known only to the speaker, it is an introducing reference (I have one friend); if it is known both to the speaker and the addressee, there is an identifying reference (This child does not listen), and if the subject is not included in the knowledge fund of the interlocutors, it is an indefinite reference (Peter married some woman) (Arutiunova 1990).

As found by Elena Levkievskaia, the mechanisms of reference used to refer to demonological phenomena differ from general linguistic rules. They are much more varied and much less standard than mechanisms used in literary language. Thus, in a demonological text, a new subject (demonological character) is introduced into a speech situation using ways that are 'deviant' as compared to those of literary language. Elena Levkievskaia points out that the narrator "persistently avoids" calling the character by a direct name, and to refer to it uses either different pronouns (he, it), or descriptions pointing to one of the character's properties, or the so-called 'relevant' names referring to an external sign as DC's distinctive feature at the moment of speech (e.g. girls in white, old man in a red shirt, etc.), or an impersonal form of the verb in subjectless sentences (e.g. frightens, appears) (Levkievskaia 2006: 197-198).

This feature of linguistic text organisation is related, according to the researcher, to the peculiarities of the communicative situation surrounding a demonological story, namely to the interlocutors' opinion about each other as equally informed on the subject matter, equally involved in the tradition, and understanding without additional comments what or who is being discussed. On the other hand, the subject of conversation (a demonological phenomenon) is incognisable in many aspects, and this cognitive uncertainty causes the referential uncertainty observed in a demonological text.

Looking into the way that the character is introduced into the narrative, how he or she is called by the narrator, and what the context of these references is, can reveal certain other regularities of referring to the $\mathrm{DC}$ in the text.

As it turned out, the DC introduction is performed in two basic ways that correspond to the two ways of the text's content organisation.

The first method of character introduction (the most frequent one, accounting for approximately $80 \%$ of all cases) is the anthroponymic name (kinship 
terms, nouns with a general categorical semantics 'person', proper names) in combination with the characteristics of the 'dead', which can take a variety of lexical and grammatical forms (died, drowned, hanged himself, deceased, etc.):

Our grandfather died (Zinov'ev 1987: № 387).

One woman's husband died. And he comes to her (Pukhova 2009:

№ 575).

One man's wife died (Zinov'ev 1987: № 386).

\section{Only the old woman who died} was in the village (Cherepanova 1996: № 10).

A young girl died, and later her mother had a dream (Pukhova 2009: № 552).

\section{There a man hanged himself}

(Cherepanova 1996: № 33).

\section{Here lived Ilyukha, who} drowned near Petushok (Cherepanova 1996: № 18).
Umer u nas ded (Zinov'ev 1987: № 387).

U odnoi zhenshchiny umer muzh. I on stal $k$ nei prikhodit' (Pukhova 2009: № 575).

Pomerla u odnogo muzhika zhena (Zinov'ev 1987: № 386).

A $v$ derevne byla tol'ko pomershaia starukha (Cherepanova 1996:

№ 10).

\section{Umerla molodaia devushka,}

a pozzhe ee materi snitsia son

(Pukhova 2009: № 552).

\section{U nikh muzhik povesilsia}

(Cherepanova 1996: № 33).

Byl tut Il'iukha, kotoryi utonul

pod Petushkom (Cherepanova 1996:

№ 18).

In this case, it is important to note that reference to the character as to the deceased, despite the predicative form (sister died, his wife died) is the most common name for a 'walking' dead man in demonological stories.

This feature corresponds to the tradition bearer's logic, described by Elena Levkievskaia, which defines a demonological character primarily through its functions (Levkievskaia 2007: 78-106), and tends to use predicative forms to represent the DC (ibid.: 174-206). Moreover, this feature is presumably a manifestation of a more general rule of naming in folklore, noted by Sergei Nekliudov - the organisation of folklore world through action: “... the character is usually defined by the type of its behaviour" (Nekliudov 1972: 213).

The second way of character introduction (much less frequent in the studied corpus) uses structures with an indefinite (rather than an introducing) reference, such as: generalised name (man, woman, and others), often in combination with indefinite pronouns (someone, some), and characteristics of appearance (usually clothes), i.e. relevant names, but also through subjectless sentences. Characters introduced into the text by indefinite reference are described by their location in space - their names are often combined with verbs of movement. 
Some man is walking along the ditch, without a cap (Cherepanova 1996: № 5).

... I come home, and there's some seventeen-year-old boy washing the floors (Pukhova 2009: № 576).

Now there is our Galka, when her son was ill, she says, a man came to her, a tall one, with a black beard, was asking for her son, but she did not give him away (Cherepanova 1996: № 29).

She stood up, opened the window, and suddenly saw a woman there, in a white dress and a headscarf, who says, "Give me some water” (Cherepanova 1996: № 30).

... A man sitting in a sheepskin coat (Cherepanova 1996: № 11).

He says, I hear the rustling (Zinov'ev 1987: № 411).
Idet muzhchina kakoi-to po kanave, bez shapki (Cherepanova 1996: № 5).

... Prikhozhu ia domoi, a tam kakoi-to iunosha 17 let moet poly (Pukhova 2009: № 576).

A vot Galka-to nasha, vot syno-ot $u$ nee bolel, tak govorit, muzhik $k$ ei prishel, vysokii takoi, s borodoi chernoi, use syna prosil, tak ne otdala ona ego (Cherepanova 1996: № 29).

$\mathrm{Nu}$, ona vstala, otkryla okoshko $i$ vdrug vidit, chto zhenshchina taka v belom plat'e i platke $i$ prosit, dai mne, mol, voditsy (Cherepanova 1996: № 30).

\section{... Sidit v tulupe muzhchina}

(Cherepanova 1996: № 11).

Slyshu, govorit, shoborchit. <...>

Shurudit (Zinov'ev 1987: № 411).

It is easy to notice that the second type of character introduction is the way of introduction specific to demonological texts, described by Elena Levkievskaia. Such texts contain an intrigue: the event is first described as trivial (indeed, is there anything unusual in the fact that a person sits, walks, goes away, washes the floors?), and only then it becomes clear that the character is a dead man.

Actually, this is the main event of the text, according to Yuri Lotman, "a meaningful deviation from the norm" (Lotman 1998: 166), and the communicative task of the text, therefore, calls for a correct identification of the character, requiring one to recognise it as a dead man. Texts of this type have a thriller plot and evoke strong emotions, especially fear. The functions they perform best are thus emotional and phatic ones, inherent in demonological stories (Levkievskaia 2008: 352-353).

The analysis showed that the texts that do not state at the outset that the story is about a dead man, have only one plot type - they describe only the fact of the dead person's appearance, and this event is sufficient for such texts.

The stories in which the listener knows in advance that the character is a dead man are more diverse in content; there are such motifs as cohabitation 
of wife and her late husband (e.g. Zinov'ev 1987: № 397; Cherepanova 1996: № 23, 24), malicious actions of the deceased towards children (Zinov'ev 1987: № 386, 399; Cherepanova 1996: № 41), identification of the deceased as a demon (Pukhova 2009: № 581-585; Cherepanova 1996: № 20, 22), protective actions (Zinov’ev 1987, № 390, 397; Pukhova 2009: № 581-595), and interaction with the demonological character - the transfer of objects to the other world (Pukhova 2009: № 547-557; Cherepanova 1996: № 46-47). There are texts, though, that have nothing but the description of a demonological character (e.g. Zinov'ev 1987: № 405; Cherepanova 1996: № 13).

In these texts the identification of the character as a dead man takes place at the beginning of the narrative, the listeners' expectations thus being prepared: the case is immediately described and perceived as supernatural, and therefore another kind of communicative task emerges - to correctly identify the character, from the standpoint of the tradition, and to teach to behave correctly in this situation (again from the viewpoint of the tradition).

Texts of this type are more informative and often didactic. Obviously, a large number of such texts in folk prose collections are due to the informants' perception of the interlocutor-folklore gatherer as a person who first of all needs information, and, importantly, information of a specific kind. Perhaps the informative orientation of these texts has caused a greater variety of motifs: the narrative serves as a clear illustration of beliefs associated with this demonological character, 'a walking dead'.

Thus, the described text types differ, depending on where in the text the character is defined as dead - at the beginning or the end of the text.

In other words, if we consider the demonological text as a statement, then we face its various theme-rheme organisation: a message that is the rheme ('new') in texts with a second type introduction, is already given in the texts of the first type, or the theme.

The observed correlation of character reference with the storyline suggests that text generation is conditioned communicatively: the introduction of different DC types 'provokes' action development through various plot schemes.

The study of the methods of introducing demonic characters in mythological narratives has revealed certain rules of naming of the DC in text. The nomination of mythological characters in oral stories does not always coincide with those names that are assigned to them in traditional beliefs (so the most common name for a 'walking dead' man in demonological stories is the anthroponymic name). The principles of mythological characters and phenomena naming are directly related to the communicative situation of telling the text and its communicative purpose for the sake of which the narrator begins to talk about the supernatural. 
A further study of this problem can be continued in research of the principles of reference of mythological characters or phenomena in different forms of presentation of traditional knowledge such as stories, legends, and beliefs.

\section{NOTES}

1 See, for example, the ethno-linguistic dictionary, The Slavic Antiquities, 1995-2012, Vol. 1-5, Moscow, as well as papers by Tatiana Agapkina, Olga Belova, Liudmila Vinogradova, Marina Vlasova, Alexander Gura, Neonila Krinichnaia, Elena Levkievskaia, Sergei Nekliudov, Anna Plotnikova, Irina Razumova, Nikita Tolstoi, Svetlana Tolstaia, and others.

2 See the review of motif-indexes of demonological prose in Nekliudov 2006.

\section{REFERENCES}

Apresian, Iurii 1995. Obraz cheloveka po dannym iazyka: Popytka sistemnogo opisaniia. [The Image of Man According to Language: An Attempt of a System Description.] Voprosy iazykoznaniia. [Questions of Linguistics.] Vol. 1, pp. 37-67. Available at ftp://istorichka.ru/Periodika/Voprosy_Jazykoznanija/1995/1995_1.pdf, last accessed on May 2, 2016.

Arutiunova, Nina 1999 [1998]. Iazyk i mir cheloveka. [Language and the World of Man.] Moscow: Iazyki russkoi kul'tury.

Arutiunova, Nina 1988. Tipy iazykovykh znachenii: Otsenka. Sobytie. Fakt. [Types of Linguistic Meanings: Evaluation. Event. Fact.] Moscow: Nauka.

Arutiunova, Nina 1990. Referentsiia. [Reference.] In: V. Iartseva (ed.) Lingvisticheskii entsiklopedicheskii slovar'. [Linguistic Encyclopaedic Dictionary.] Moscow: Sovetskaia entsiklopediia, pp. 411-412. Available at http://tapemark.narod.ru/ les/411a.html, last accessed on May 2, 2016.

Cherepanova, Ol'ga (ed.) 1996. Mifologicheskie rasskazy i legendy Russkogo Severa. [Demonological Stories and Legends of the Russian North.] Sankt-Peterburg: Izdvo S.-Peterburgskogo universiteta. Available at http://www.booksite.ru/fulltext/ $\mathrm{mip} / \mathrm{hol} /$ ogi/che/skye/, last accessed on May 2, 2016.

Levkievskaia, Elena 2006. Pragmatika mifologicheskogo teksta. [Pragmatics of Demonological Text.] Slavianskii $i$ balkanskii fol'klor: Semantika i pragmatika teksta, Vyp. 10. [Slavic and Balkan Folklore: Semantics and Pragmatics of the Text.] Moscow: Izdatel'stvo Indrik, pp. 150-213. Available at https://vk.com/doc4520 2459_437384636?hash=3cd92e62948e08abf7\&dl=3671a2f2d04dc2c060, last accessed on May 2, 2016.

Levkievskaia, Elena 2007. Vostochnoslavianskii mifologicheskii tekst: semantika, dialektologiia, pragmatika. [East Slavic Demonological Text: Semantics, Dialectology, Pragmatics.] Diss. (PhD thesis). Moscow: Institut slavianovedeniia RAN. Available at http://www.dslib.net/jazyki-slavian/vostochnoslavjanskijmifologicheskij-tekst-semantika-dialektologija-pragmatika.html, last accessed on May 2, 2016. 
Levkievskaia, Elena 2008. Bylichka kak rechevoi zhanr. [Bylichka as a Speech Genre.] In: A. Arkhipova \& M. Gister (comp.) Kirpichiki: fol'kloristika i kul'turnaia antropologiia segodnia. [Bricks: Folklore and Cultural Anthropology Today.] Moscow: Rossiiskii gosudarstvennyi gumanitarnyi universitet, pp. 341-363.

Lotman, Iurii 1998. Struktura khudozhestvennogo teksta. [The Structure of the Art Text.] In: Iu. Lotman (ed.) Ob iskusstve. [About Art.] Sankt Peterburg: Iskusstvo SPb, pp. 14-285. Available at http://www.ruthenia.ru/lotman/papers/sht/, last accessed on May 2, 2016.

Nekliudov, Sergei 1972. Osobennosti izobrazitel'noi sistemy v doliteraturnom povestvovatel'nom iskusstve. [The Specifics of Imagery System in Pre-Literary Narrative Art.] In: S. Nekliudov \& E. Meletinskii (eds.) Rannie formy iskusstva. [Early Forms of Art.] Moscow: Iskusstvo, pp. 191-220.

Nekliudov, Sergei 2006. Ukazateli fol'klornykh siuzhetov i motivov: k voprosu o sovremennom sostoianii problemy. [Motif-Indexes of Folklore: About the Current State of the Problem.] In: A. Rafaeva (comp.) Problemy strukturno-semanticheskikh ukazatelei. [Problems of Structural and Semantic Indexes.] Moscow: Izdatel'stvo RGGU, pp. 31-37.

Pukhova, Tat'iana (ed.) 2009. Bylichki i byval'shchiny Voronezhskogo kraia. [Demonological Narratives of the Voronezh Region.] Voronezh: Nauchnaia kniga.

RCS 1983 = Russkaia razgovornaia rech': Fonetika. Morfologiia. Leksika. Zhest. [Russian Colloquial Speech: Phonetics. Morphology. Lexis. Gesture.] Edited by E. Zemskaia. Moscow: Nauka.

RSD 1998 = Russkii semanticheskii slovar'. Tom I: Slova ukazuiushchie (mestoimeniia). Slova imenuiushchie: imena sushchestvitel'nye. [Russian Semantic Dictionary. Vol. 1: Words That Point (Pronouns). Words That Name: Nouns.] Moscow: Azbukovnik.

Shmelev, Aleksei 2002. Russkaia iazykovaia model' mira: materialy k slovariu. [Russian Linguistic World Model: Materials for a Dictionary.] Moscow: Iazyki slavianskoi kul'tury.

Uryson, Elena 1998. Iazykovaia kartina mira vs obikhodnye predstavleniia (model' vospriiatiia v russkom iazyke). [Linguistic Worldview vs. Everyday Representation.] Voprosy iazykoznaniia, Vol. 2, pp. 3-21. Available at http://www.ruslang.ru/doc/ voprosy/voprosy1998-2.pdf, last accessed on May 3, 2016.

Vinogradova, Liudmila \& Levkievskaia, Elena (eds.) 2012. Narodnaia demonologiia Poles'ia: Publikatsii tekstov v zapisiakh 80-90-kh godov XX veka. T. 2. [Folk Demonology of Polesye: Publications of Texts Recorded in the 80s-90s of the 20th Century. Vol. 2.] Moscow: Rukopisnye pamiatniki Drevnei Rusi.

Wierzbicka, Anna 1997. Understanding Cultures Through Their Key Words: English, Russian, Polish, German, and Japanese. New York \& Oxford: Oxford University Press. Available at https://archive.org/stream/ UnderstandingCulturesThroughTheirKeyWords/Understanding\%20Cultures\%20 Through\%20Their\%20Key\%20Words_djvu.txt, last accessed on May 3, 2016.

Zemskaia, Elena 1979. Russkaia razgovornaia rech': lingvisticheskii analiz i problemy obucheniia. [Russian Colloquial Speech: Linguistic Analysis and Issues of Teaching.] Moscow: Russkii iazyk.

Zinov'ev, Valerii (ed.) 1987. Mifologicheskie rasskazy russkogo naseleniia Vostochnoi Sibiri. [Demonological Stories of the Russian Opulation in Eastern Siberia.] Novosibirsk: Nauka. 